Chirurgia (2020) 115: 252-260

No. 2, March - April

Copyright@ Celsius

http://dx.doi.org/10.21614/chirurgia.115.2.252

\title{
Hepatoportoenterostomy in Selective Obstructive Cholestasis - An New Experimental Model in the Rat
}

\author{
Raluca-Cristina Apostu ${ }^{1,2}$, Catalin C Ciuce ${ }^{1,2}$, Vlad Făgărășan ${ }^{1,2}$, Radu Razvan Scurtu ${ }^{1,2}$, Constantin Ciuce ${ }^{1,2}$ \\ "Iuliu Hațieganu” University of Medicine and Pharmacy, Cluj-Napoca, Romania \\ ${ }^{2}$ First Surgical Clinic, Cluj-Napoca, Romania
}

Corresponding author:

Radu R Scurtu, MD, PhD

"Iuliu Hatieganu" University of Medicine and Pharmacy Cluj-Napoca

First Surgical Clinic Cluj-Napoca, 3-5

Clinicilor Street, Cluj-Napoca, Romania

E-mail: rrscurtu@yahoo.com

\section{Rezumat}

Hepatoportoenterostomia în colestaza obstructivă selectivă - un nou model experimental pe șobolan

Introducere:Atrezia biliară reprezintă cea mai frecventa cauză de colestază obstructivă neonatală. În prezent, hepatoportoenterostomia (HPE) este singura modalitate de prelungire a vieții până în momentul efectuării transplantului hepatic, cea mai mare rată de succes fiind înregistrată în primele 60 de zile de viață.

Scop:Ne-am propus să elaborăm un model experimental de drenaj al colestazei obstructive prin intermediul HPE.

Material şi metodă: Obstrucția căilor biliare a fost indusă prin ligatura selectivă a ductelor corespunzătoare lobilor hepatici median şi lateral stâng, la 20 de şobolani rasa Wistar. La 4 săptămâni postoperator $\mathrm{s}$-a reintervenit chirurgical în vederea realizării drenajului biliar prin HPE. Integritatea anastomozei şi modificările hepatice s-au evaluat după o săptămână.

Rezultate: Rata de supraviețuire a fost de 90\%. Reintervenția chirurgicală a evidențiat aderențe hepato-biliare, cu fibroză la nivelul hilului hepatic. Microscopic s-a evidențiat fibroza incipientă cu colestază moderată. După efectuarea HPE nu s-a decelat extravazare de bilă la nivelul anastomozei sau peritonită biliară. Evolutia a fost marcată de reducerea alimentatiei.

Concluzii: Modelul experimental propus pentru HPE este fiabil prin utilizarea tehnicilor de microchirurgie. Pe baza acestuia se pot studia modificările induse de obstrucția ductelor biliare.

Cuvinte cheie: atrezie biliară, drenaj biliar, colestază, experimental, portoenterostomie 


\section{Abstract}

Backgrounds: Biliary atresia is the most frequent cause for neonatal obstructive cholestasis. Hepatoportoenterostomy (HPE) is the only method allowing survival until liver transplantation. For a maximum rate of success, the HPE procedure has to be performed within the 60 days of life. We aimed to create an experimental model for relieving obstructive cholestasis.

Methods:In 20 Wistar rats selective bile duct obstruction was induced by the microsurgical ligature of the bile ducts corresponding to the median and left lateral liver lobes. After four weeks surgical re-intervention was carried out and HPE was performed microsurgically on the hilum of the median and left lateral liver lobes. One week after HPE, the integrity of the anastomosis and the hepatic changes were assessed.

Results: The survival rate throughout the study was $90 \%$. The surgical re-intervention revealed hepatic-hilum adhesions, with fibrosis. Microscopically, an initial fibrogenic repair was identified, equivalent of moderate cholestasis. After the HPE, there was no bile leak from the anastomosis and no biliary peritonitis. The evolution was marked by a reduction in food intake.

Conclusions: The experimental model we propose for the HPE is reliable by using microsurgical techniques. Based on it, one can study the changes induced by the bile duct obstruction.

Key words: biliary atresia, biliary drainage, cholestasis, experimental, portoenterostomy

\section{Introduction}

Biliary atresia (BA) is a rare perinatal pathology, with unknown etiology. The mechanisms responsible for BA are explained by several theories, involving immunologic factors, genetics, ischemia or infection (1). Progressive obstructive cholestasis is a key element of BA and, if not addressed, it eventually leads to liver failure and to patients' death. Despite the reported progress (2) in the management of BA and the subsequent cholestasis, the only alternative to efficiently relieve cholestasis on the long term in BA is liver transplantation. However, due to shortage of suitable liver donors and the adverse effects of lifelong immunosuppression non-transplant approaches are favoured as a first step. The internal drainage of the dilated intrahepatic biliary tree by the means of a Roux-en-Y jejunal loop - hepatoportoentero-stomy (HPE) - is lifesaving until a transplant becomes available. With this type of surgical procedure, patients can achieve a $88 \%$ survival rate at 5-years with their native liver, while the 10-year survival rate can be up to $77 \%(2,3)$.

Failure of HPE is frequent due to cholangitis and fibrosis and ultimately results in biliary cirrhosis. Several approaches aiming at controlling inflammation and improving the bile flow by means of corticosteroids, diet or ursodeoxycholic acid have yielded conflicting or inconclusive results. Given the relative rarity of this condition and the difficulty of performing randomized, controlled trials in this vulnerable patient population, animal studies could provide valuable information on the injury and repair processes after the biliary drainage by means of HPE. Several straightforward rodent models have been suggested, most involving the ligature of the common bile duct. However, this intervention is often associated with excessively high mortality and complications, such as hilum pseudocyst, ascites and hepatosplenomegaly $(4,5)$.

Therefore, we aimed to develop a novel experimental model of HPE in the rat, a robust, adequately sized and cheap species using a two-stage microsurgical approach.

In order to induce the obstructive cholestasis, we have chosen a micro-surgical technique, because in the macro-surgical model, the ligature of the common bile duct was associated with higher mortality and 
complications, such as hilum infected pseudocyst, ascites, hepato-splenomegaly, while microsurgery avoided these complications (6).

\section{Material and Method}

\section{Experimental Design}

The experiment consisted in two surgical steps. The first surgical procedure was performed in 20 rats and consisted in creating a proximal biliary obstruction by resecting the bile ducts in two hepatic lobes: median and left lateral with a follow-up of 4 weeks. In 16 rats, a second surgical procedure was performed and a HPE was performed between the hepatic parenchyma and an enteral loop in the hilum of the two hepatic lobes with previous bile duct resection, after the liver lobes were biopsied. A number of 4 rats were kept as a control group. Animals were monitored for food intake and complications. A week after the HPE, a re-laparotomy was performed in all rats in order to assess the macroscopic changes and to perform liver biopsies for histologic assessment.

The study design was approved by the Ethic Committee of "Iuliu Hațieganu" University of Medicine and Pharmacy.

\section{Animals}

Female Wistar rats weighing 250-300 g were used. All animals were maintained in the animal facility of "Iuliu Hațieganu" University of Medicine and Pharmacy in Cluj-Napoca, on standard laboratory diet and water ad libitum.

\section{Surgical Protocol}

\section{Anaesthesia}

The animals were anaesthetized using a Ketamine and Xylazine based protocol. The necessary dose of Ketamine was $80 \mathrm{mg} / \mathrm{kg}$ and Xylazine $8 \mathrm{mg} / \mathrm{kg}$. A combination of the two substances was obtained in a 2:1 proportion Ketamine 10\%: Xylazine $2 \%$ in an insulin syringe sized $100 \mathrm{UI} / \mathrm{ml}$. The animals were weighed. An 18 UI solution was administered for $150 \mathrm{~g}$ and for every $25 \mathrm{~g}$ excess weight, $3 \mathrm{UI}$ were added. If necessary, a reminder dose was administered using 4 UI Ketamine 10\%.

\section{Microscopic bile duct ligature}

In all 20 Wistar rats, a laparotomy was performed using a midline incision. The liver was retracted in cranial position and the bile ducts of the four liver lobes were exposed (Fig. 1A). The bile ducts of the median and left lateral lobes, accounting for about $60 \%$ of the liver volume, were identified and ligatured with 7-0 polypropylene near the hepatic parenchyma with a second ligature placed distally at 0.5 centimetres to the first one (Fig. 1B). The bile ducts between ligatures were excised (Fig. $2 A, B$ ). A part of the common bile duct collecting the bile from the two hepatic lobes was also excised between ligatures. The bile ducts of the right lateral and caudate lobes were left intact. A parenchymal connection between the right lateral and median lobe was searched in order to avoid biliary drainage through collateral ducts. The abdominal wall was closed using an 6.0 continuous suture made of polypropylene.

The presence of jaundice was evaluated, as reported by Yunfu et al, by visual evaluation of the eyes and skin (ears and tails) colour, on day by day basis (7).

\section{Hepatoportoenterostomy}

After four weeks, 16 rats were selected for a second surgical procedure and four animals were kept as a control group, in order to evaluate their survival and quality of life. A re-laparotomy was performed and the macroscopic and microscopic changes were assessed. The hepatic lobes were biopsied. The adhesions were sectioned and the hepatic hilum was exposed. The fibrous tissue identified in the hilum of the median and left lateral lobes was excised proximal to the excised segment of the bile duct, with adjacent hepatic parenchyma, delineating an area of approximately 0.7 square centimetres (Fig. 3). The second jejunal loop (5 cm distal from Treitz lig- 


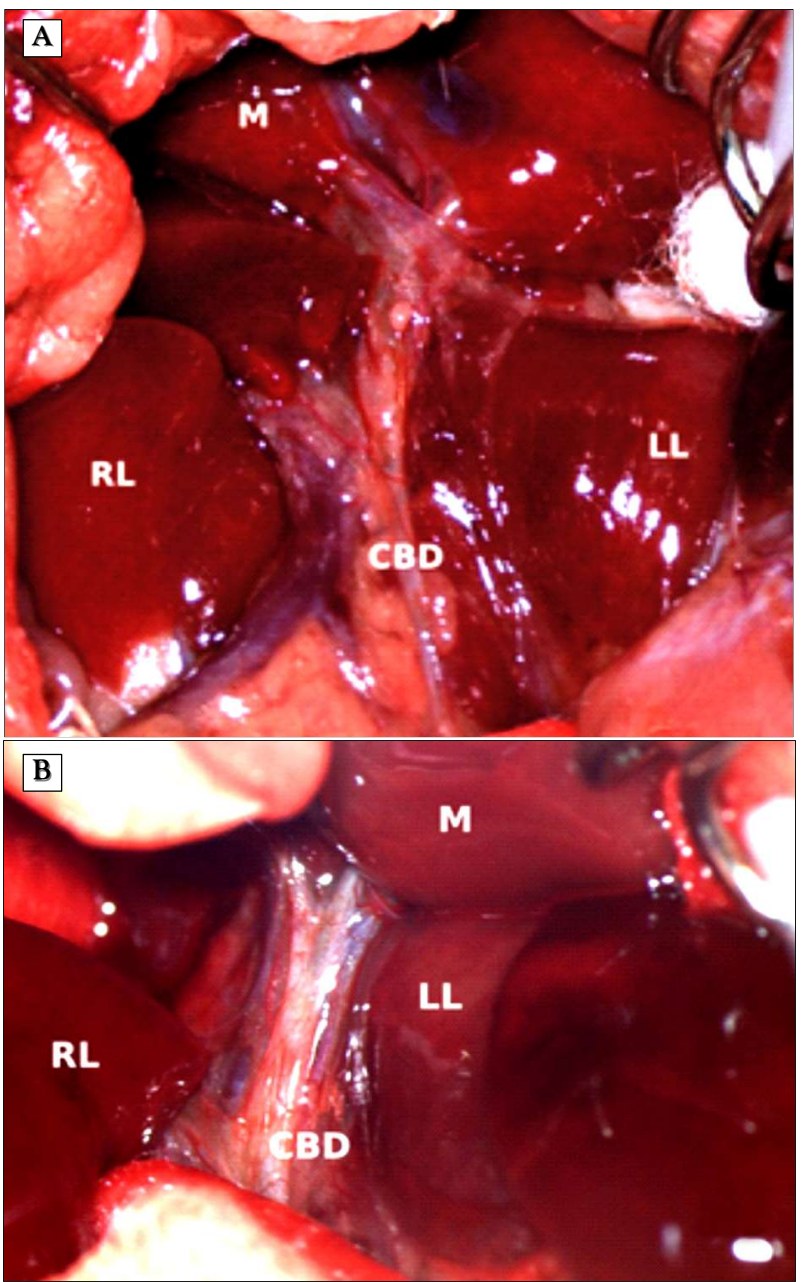

Figure 1. Hepatic hilum dissection. The hepatic hilum is exposed and the bile ducts are identified and dissected (microscopic view): (A) - hepatic hilum (x16); (B) - common bile duct (x40)

M - median hepatic lobe; RL- right lateral hepatic lobe; LL- left lateral hepatic lobe; CBD - common bile duct.

ament) was mobilized as an Roux-en-Y loop and sutured over the raw hepatic parenchyma using a 9.0 continuous polypropylene suture (Fig. 4A,B).

The biopsied tissue was analyzed microscopically, using HE staining and testing the positivity of fibrosis markers (Fig. 5).

One week later, a re-laparotomy was performed once again in all 16 rats and the macroscopic changes were assessed. At the end of the procedure, the entire group was sacrificed using an anaesthetic overdose.

The pathological changes in the abdominal cavity were assessed macroscopically. The

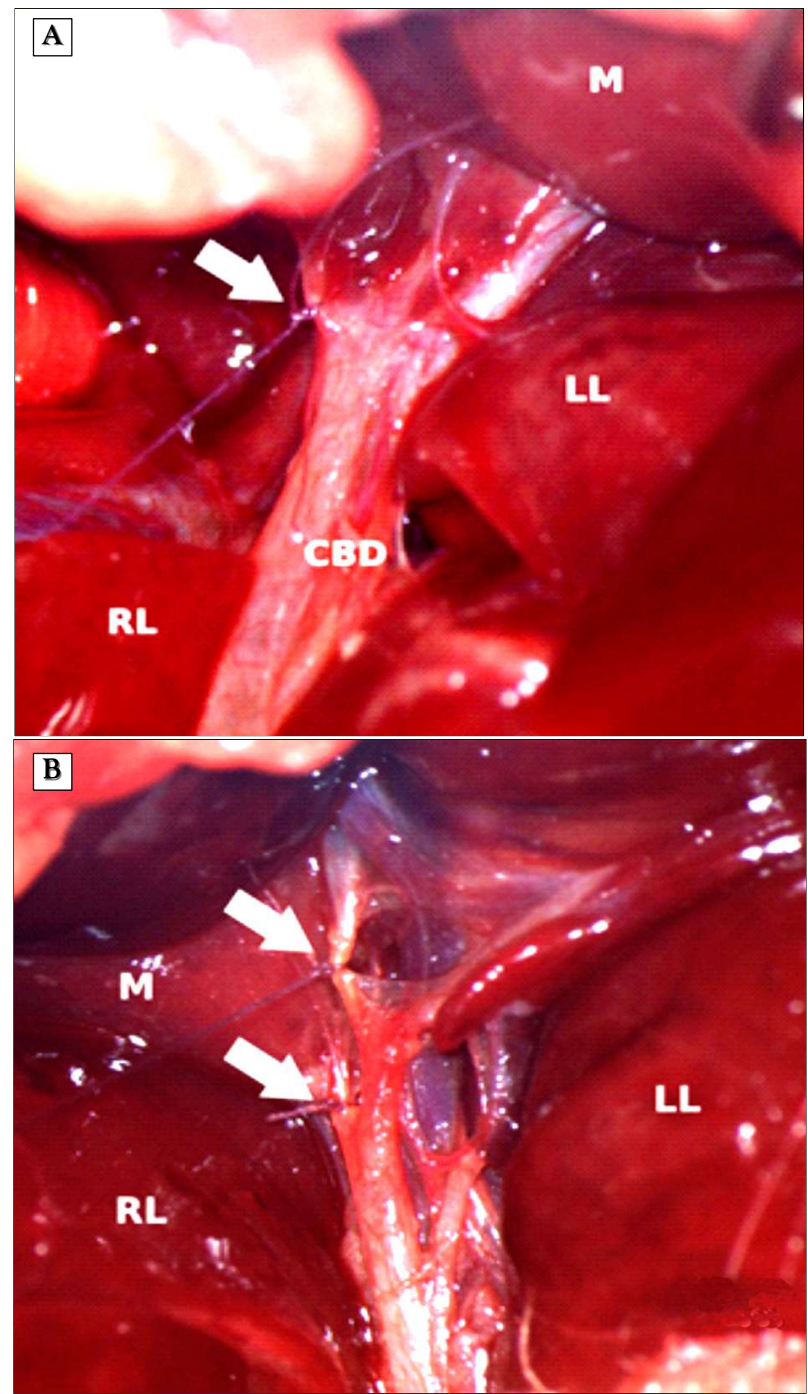

Figure 2. Bile ducts ligation. Bile duct ligature at the hilum of the median lobe $(x 40)$ : $(\mathbf{A})$ - bile duct to the median lobe with distal ligature (arrow); (B) - after complete dissection of the hilum of the median lobe, ligatures were placed (arrows)

M - median hepatic lobe; RL- right lateral hepatic lobe; LL- left lateral hepatic lobe; $\mathrm{CBD}$ - common bile duct.

surgical procedures were performed and photographed using a Leica binocular microscope.

\section{Results}

Throughout the study, the survival rate was $90 \%$. Death occurred in two rats (10\%) because of an important bleeding from the hepatic lobes, during the second surgical procedure. Jaundice was absent in all rats, whether the hepatoportoenetrostomy was 


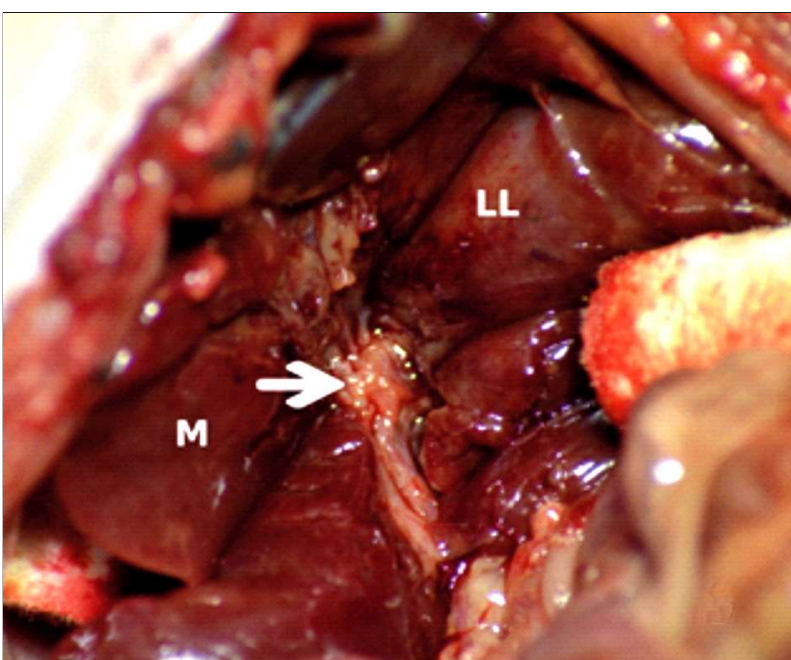

Figure 3. Macroscopic aspect. Fibrous tissue at the hilum of the median and left lateral lobe (arrow).

M - median hepatic lobe; LL- left lateral hepatic lobe.

performed or not. No parenchymal connection was identified between the median and right lateral hepatic lobes. In 10 rats, wound complications were registered 2 weeks after the first surgical procedure. In six animals, partial wound dehiscence was noticed, with local secretions. After wound cleaning and local antibiotherapy, the evolution was favourable with granulation and complete healing until the second surgical procedure. In

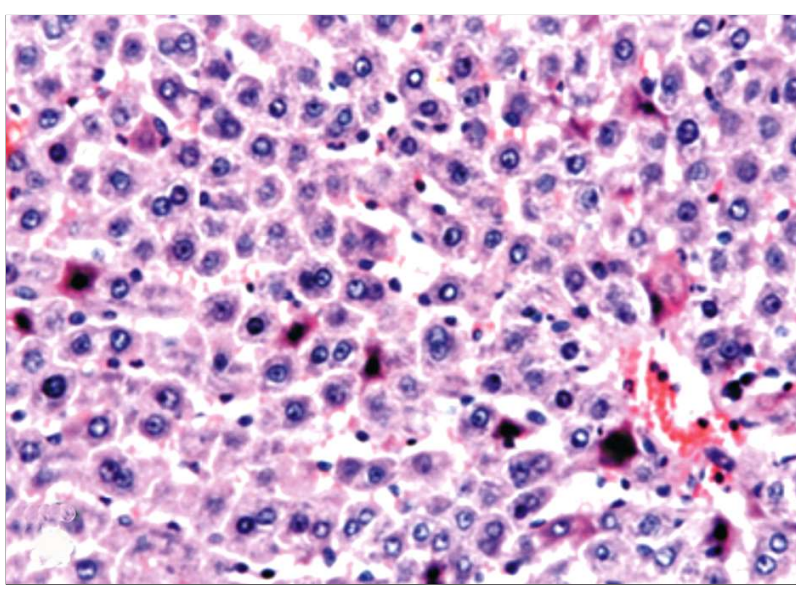

Figure 5. Microscopic aspect after 4 weeks of bile ducts ligature $(\mathrm{HE} \times \mathrm{40})$. Pericentrolobular activated stellate Ito cells, that mark the onset of fibrogenesis: stellate cells with hipercrome, condensed nucleus and hypereosinophilic cytoplasm; the cells were also positive for fibrotic markers.

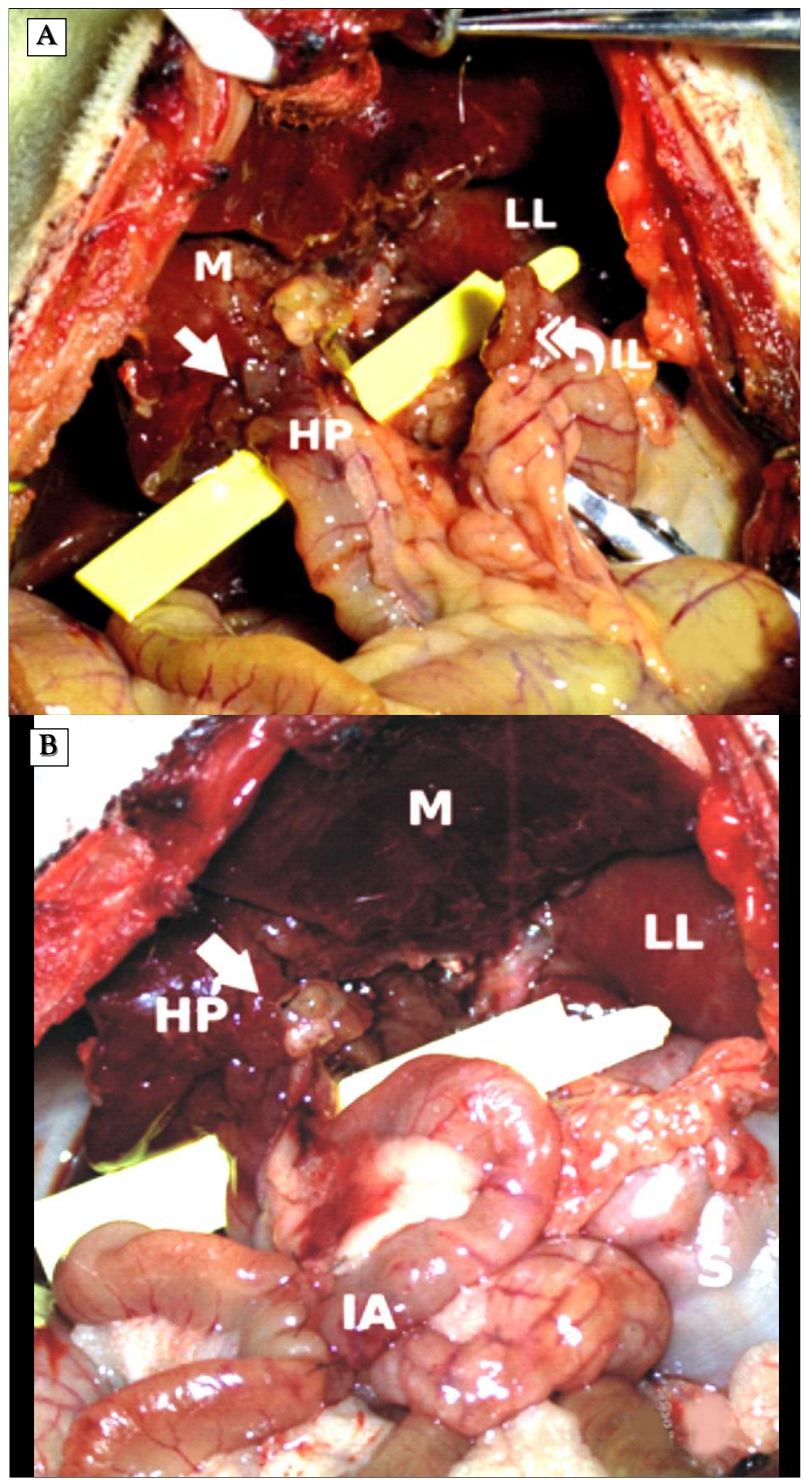

Figure 4. Hepatoportoenterostomy. (A) - Anastomosis in the median lobe (HP, arrow) and the proximal enteral end (IL, curved arrow); (B) - Portoenterostomy in the median hilum (HP, arrow) and entero-enteral anastomosis $(\mathrm{IA})$.

M - median hepatic lobe; LL- left lateral hepatic lobe; IL- intestinal loop; HP - hepatoportoenterostomy; IA - intestinal anastomosis.

other 4 rats, eventration (abdominal wall hernia) was noticed, which was solved during the second surgical procedure by direct suture. The second operation revealed adhesions between the liver capsule and the hepatic hilum. The microscopic analysis revealed an incipient fibrogenic process, with moderate, chronic cholestasis. A positive expression of the fibrotic markers was also identified. After 
cutting the adhesions, the hilum was exposed and a fibrous tissue was noticed in the area where the bile ducts were ligated, corresponding to the median and left lateral liver lobes. In the area where the fibrous tissue was excised with the adjacent hepatic parenchyma, no remarkably dilated bile ducts were identified. After the second procedure, no wound complications were registered, but local antibiotic prophylaxis was performed. One week after the HPE, there were no signs of dehiscence or bile extravasation from the hepato-enteral anastomosis and no signs of biliary peritonitis. We also noticed a reduction in food intake for the entire group. Rats in the control group, despite losing weight, had an almost normal activity.

\section{Discussions}

Biliary atresia (BA) has an accelerated evolution towards biliary cirrhosis, if an efficient drainage is not performed in time (8). Attempts to reproduce the pathological mechanism of the disease in order to study it and improve treatment are expected. However, because BA is the result of multiple pathogenic mechanisms, attempts have been made mostly in order to relieve or to delay cholestasis effects on the liver function. The choice to study obstructive cholestasis on rats turned out to be advantageous. An average survival rate of $83 \%$ was reported in studies where a single surgical procedure was performed. Deaths were preceded by bleeding secondary to sectioning the parenchymal connection between the lobes (9). In our study, the majority of animals survived to both surgical procedures, with an overall survival rate of $90 \%$. We recorded only two deaths after the surgical re-intervention because of major bleeding.

A number of studies have obtained cholestasis by bile duct ligature in rats. Macroand micro-surgical procedures were compared and the macro-surgical procedures had bigger rates of post-operative morbidity. Beyond the risk of recanalization, there were also other complications like hilum biliary pseudocyst, hepatosplenomegaly, abscesses or death $(5,6)$. In this study, we proposed a double microsurgical ligature of the bile ducts, in the area they enter the hepatic parenchyma, with the resection of the biliary segment between ligatures, in order to avoid recanalization. None of the above mentioned complications were associated with this method.

All models that were based on the ligation of all the biliary ducts had an induced obstructive jaundice (6). The absence of jaundice in our study might be explained by the fact that we performed a selective bile duct resection. The four hepatic lobes of the anatomically normal rat allowed us to choose only two lobes for the procedure while preserving the other two. Tannuri et al. also reported the absence of the post-operative jaundice, even though they ligated and resected between ligatures, the bile ducts of three hepatic lobes, with only the fourth one left intact (9).

In the experimental group, the major postoperative complication has been the wound infection. Given the fact that dehiscence appeared two weeks after the first surgery, it was probably not related to the procedure. There is a general tendency of the rat with obstructive biliary drainage to develop infections, as described by Aller et al (6). But it was represented by peritoneal abscesses or systemic sepsis. In our model, the infection was superficial and had a rapid evolution towards healing using only local conservative treatment.

The eventration (abdominal wall hernia) was not described as a complication in other experimental models using the same abdominal wall closure technique (6). Their presence had no influence on the study and it was easily solved by direct suture.

It is known that after the bile duct ligature, the fibrotic changes are maximal after four weeks $(9,10)$. The presence of the fibrous tissue could be explained by the anterior dissection performed in the area of the hepatic hilum and the resection of the bile ducts. Another important fact in discovering the ductules is wide dissection and resection of the portal fibrous remnant, as the micro- 
biliary ductules can be mostly distributed laterally, not medially. Also, the number of ductules in the proximal end was observed to be the most within $2 \mathrm{~mm}$ from the transection area, decreasing gradually to the distal end (11). In this experimental model, the purpose of bile duct obstruction was to induce hepatic alterations similar to those determined by the cholestatic diseases.

We performed the resection of the fibrous tissue adjacent to the hepatic parenchyma, where no proximal segment of the bile ducts where identified. After the resection, in the created area no dilated bile ducts were spotted. In similar models, only histological and molecular changes are described (9), which could suggest that in order to have secondary dilated bile ducts, the obstruction needs to be extended. In this context, in order to prove the utility of this model, identification of fibrosis in the chosen period of time was considered sufficient.

It is already proven that in infants with cholestasis the characteristic histologic findings that predicts biliary atresia are bile ducts proliferation, ductular bile plugs, portal stromal edema, peribiliary neutrophilic infiltrates, bile ducts injury, portal fibrosis $(12,13)$. Although there are reports in the literature stating that the accuracy of liver biopsies is not influenced by age (<60 days) (14), other authors have proved, by comparing sequential histological findings, that the characteristic changes can be sparse initially, with only one or two elements present, and that a definitive biopsy can be obtained as early as 35 days of age, with a median of 3 weeks between the first and the definitive one. This is a known reason for delaying diagnosis (15).

The difficulty to obtain obstructive cholestasis in the selective bile duct ligature, for reasons of accessory bile ducts, is highlighted in other studies. They were able to achieve histological alterations only after sectioning the parenchymal connection between the hepatic lobes (9). It would be expected therefore to have minimal histological changes, in a experimental microsurgical liver model. Cholestasis, despite the absence of jaundice, can be demon- strated, in its early stages even by histological analysis. Taking into consideration that there is a hetero-geneous response of each hepatic lobe to the bile ducts obstruction, which have been demonstrated by the histological alterations (6), we could conclude that it would be necessary to reduce the capacity of the extrahepatic bile tract to a greater degree than a selective ligation as the microsurgical technique can achieve, for the jaundice to be present.

The standard principles of Kasai's hepatoportoenterostomy include complete resection of the portions of the extrahepatic biliary system and reinstatement of bile flow through an anastomosis between the jejunum and the porta hepatis (16). Different modifications to the procedure have been proposed in order to improve outcome and reduce risk of complications. Even though the level of transection proved to be more important than the type of reconstruction, or that the significance of an intestinal valve on the final outcome is controversial, a limited and careful resection of the fibrous remnant and a meticulous anastomosis were the basic details associated with favourable outcomes (17).

A HPE model in rat was not described before. Other types of bilio-jejunal anastomosis have been described in rats. One model was a diversion in diabetic rats, where Lambert prosthetic choledoco-jejunostomy was performed (10) and the other one was a Roux-en-Y bilio-jejunal anastomosis performed as a method of biliary drainage after the common bile duct ligature (18). A choledoco-jejunal anastomosis was also described in dogs as a method of biliary drainage after bile duct injury (19). Practically, the efficiency of a choledocojejunal anastomosis was assessed. In our study, by resecting the bile ducts adjacent to the hepatic parenchyma, a bilio-jejunal anastomosis was impossible to realize and HPE was an effective solution. The liver parenchyma is a hemorrhagic and friable tissue. Deaths were registered in other models following bleeding secondary to less invasive maneuvers (18). In our case, in order to perform a partial resection of the parenchyma with the hepato-jejunal anastomosis and to 
ensure the rat survival, the technique had to be flawless. Despite a very careful surgical technique, two rats died because of an important bleeding. A more prominent fibrotic transformation of the liver would be an advantage, a hard hepatic capsule being an important element in the anastomosis. We assessed the HPE after one week. There were no signs to suggest a dehiscence or bile extravasation through the anastomosis.

\section{Conclusions}

HPE is the only surgical procedure allowing a delay in the progress of hepatic alteration and with a long term native liver survival up to $44 \%$ (20). Despite that, $50 \%$ of patients require liver transplant two years after surgery (9), a reason to bring forth the need for further studies for understanding the pathogenic mechanisms of the disease and for treatment improvements.

The use of rats instead of mice had the advantage of an easier manipulation of the liver and a larger work area. Despite the absence of the gallbladder, the anatomy of the rat with four liver lobes (21), allowed us to induce hepatic changes in two of these, while using the remaining healthy ones as a control, and thus, having the experimental and the control liver on the same animal.

By creating this experimental model, we ascertained the fact that it is possible to obtain a reproducible and accessible training prototype, using microsurgical techniques. Relying on the short term findings emphasised in this paper, the model allows the study of this not fully understood pathology. It is an up-to-date problem to find new ways to increase survival in this rare disease and the above mentioned reasons are a strong mobile for our experiments.

\section{Conflicts of interests}

The Authors declare no conflicts of interest. We disclose all financial and material support.

\section{Ethics Approval}

The study design was approved by the Ethic Committee of "Iuliu Hatieganu" University of Medicine and Pharmacy, Cluj-Napoca, Romania (Nr. 81/01.02.2018).

\section{Author's Contributions}

All authors contributed equally to this work.

\section{References}

1. Jimenez-Rivera C, Jolin-Dahel KS, Fortinsky KJ, Gozdyra P, Benchimol El. International incidence and outcomes of biliary atresia. J Pediatr Gastroenterol Nutr. 2013;56(4):344-354.

2. Gu YH, Yokoyama K, Mizuta K, Tsuchioka T, Kudo T, Sasaki H et al. Stool color card screening for early detection of biliary atresia and Iong-term native liver survival: a 19-year cohort study in Japan. J Pediatr. 2015;166(4):897-902 e891.

3. Lopez RN, Ooi CY, Krishnan U. Early and Peri-operative Prognostic Indicators in Infants Undergoing Hepatic Portoenterostomy for Biliary Atresia: a Review. Curr Gastroenterol Rep. 2017;19(4):16.

4. Petersen C. Biliary atresia: the animal models. Semin Pediatr Surg. 2012;21(3):185-191.

5. Santos JL, Carvalho E, Bezerra JA. Advances in biliary atresia: from patient care to research. Braz J Med Biol Res. 2010;43(6):522-527.

6. Aller MA, Duran M, Ortega L, Arias JL, Nava MP, Prieto I et al. Comparative study of macro- and microsurgical extrahepatic cholestasis in the rat. Microsurgery. 2004;24(6):442-447.

7. Yunfu Lv, Jie Yue, Xiaoguang Gong, Xiaoyu Han, Hongfei Wu, Jie Deng et al. Spontaneous remission of obstructive jaundice in rats: Selection of experimental models. Experimental and Therapeutic Medicine (Internet). 2018;15(6):5295-5301.

8. Lakshminarayanan B, Davenport M. Biliary atresia: A comprehensive review. J Autoimmun. 2016;73:1-9.

9. Tannuri AC, Coelho MC, de Oliveira Goncalves J, Santos MM, Ferraz da Silva LF, Bendit I et al. Effects of selective bile duct ligation on liver parenchyma in young animals: histologic and molecular evaluations. J Pediatr Surg. 2012;47(3):513-522.

10. Popov Y, Sverdlov DY, Bhaskar KR, Sharma AK, Millonig G, Patsenker $E$ et al. Macrophage-mediated phagocytosis of apoptotic cholangiocytes contributes to reversal of experimental biliary fibrosis. Am J Physiol Gastrointest Liver Physiol. 2010; 298(3):G323-334.

11. Yang J, Wei N, Su Y, Wei M, Yi B, Feng J. A morphology-based analysis of biliary ductules after Kasai procedure and a review of the literature. J Surg Res 2020;251:180-186.

12. Russo P, Magee JC, Boitnott J, Bove KE, Raghunathan T, Finegold $\mathrm{M}$, et al. Biliary Atresia Research Consortium. Clin Gastroenterol Hepatol 2011;9(4):357-362.

13. Russo P, Magee JC, Anders RA, Bove KE, Chung C, Cummings OW, et al. Childhood Liver Disease Research Network (ChiLDReN). Am J Surg Pathol 2016;40(12):1601-1615. 
14. Mandelia A, Lal R, Mutt N. Role of hepatobiliary scintigraphy and preoperative liver biopsy for exclusion of biliary atresia in neonatal cholestasis syndrome. Indian J Pediatr 2017;84: 685-690.

15. Lemoine C, Melin-Aldana H, Brandt K, Mohammad S, Superina R. The evolution of early liver biopsy findings in babies with jaundice may delay the diagnosis and treatment of biliary atresia. J Pediatr Surg 2020. Available at https://doi.org/10.1016/j.jpedsurg.2020.01.027.

16. Parl CJ, Armenia SJ, Keung CH, Compton JT, Cowles RA. Surgical modifications of the Kasai hepatoportoenterostomy minimize invasiveness without compromising short- and medium-term outcomes. J Pediatr Surg 2019;54(3):537-542.

17. Nio M, Wada M, Sasaki H, Kazama T, Tanaka H, Kudo H. Technical standardization of Kasai portoenterostomy for biliary atresia. J Pediatr Surg 2016;51(12):2105-2108.
18. Ermini M, laconis E, Mori A. The effects of Bilio-Jejunal Diversion on Streptozocin Diabetes in the rat. Acta Diabetol Lat. 1991;28 (1):79-89.

19. TretYakov AA, Kagan II, Neverov AN, Dronova OB, Petrov SV, Kuznetsov IR. Reconstructive and Restorative Operations on Extrahepatic Bile Ducts using Microsurgical Technologies: Experimental Substantiation and Clinical Experience. Vest Khir Im I I Grek. 2016;175(4):40-45.

20. Novo E, di Bonzo LV, Cannito S, Colombatto S, Parola M. Hepatic myofibroblasts: a heterogeneous population of multifunctional cells in liver fibrogenesis. Int J Biochem Cell Biol. 2009;41(11): 2089-2093.

21. Suckow MA, Weisbroth SH, Franklin CL. The laboratory rat. 2nd ed. Amsterdam ; Boston: Elsevier; 2006. 